\title{
Targeted therapies for advanced and metastatic adenocarcinoma of the gastroesophageal junction: is there something new?
}

\author{
Felice Pasini $^{1}$ - Anna Paola Fraccon ${ }^{2} \cdot$ Yasmina Modena $^{1} \cdot$ Maria Bencivenga $^{3}$ • \\ Simone Giacopuzzi ${ }^{3} \cdot$ Francesca La Russa $^{1} \cdot$ Milena Gusella $^{1} \cdot$ Giovanni de Manzoni $^{3}$
}

Received: 3 January 2016/ Accepted: 2 August 2016/Published online: 27 August 2016

(c) The International Gastric Cancer Association and The Japanese Gastric Cancer Association 2016

\begin{abstract}
Despite improvements in systemic chemotherapy (CT), the prognosis of metastatic adenocarcinoma of the gastroesophageal junction remains poor. Over the years, new targeting agents have become available and were tested, with or without CT, in first or subsequent lines of therapy. The epidermal growth factor receptor family was targeted with monoclonal antibodies (MoAbs) (trastuzumab, cetuximab, panitumumab) and tyrosin kinase inhibitors (TKIs) (lapatinib, erlotinib, gefitinib). Only trastuzumab, in combination with cisplatin and fluoropyrimidines, significantly improved overall survival (OS) in first-line therapy (13.8 vs. 11.1 months). Angiogenesis also was targeted with MoAbs (bevacizumab and ramucirumab); ramucirumab, a vascular endothelial growth factor-receptor 2 antagonist, enhanced OS in two phase III studies in the first (9.6 vs. 7.4 months) and subsequent lines of treatment (5.2 vs. 3.8 months), while the bevacizumab study was negative. TKIs (sunitinib, sorafenib, regorafenib, apatinib) were tested in this setting in phase II studies in the second/third line, only showing modest antitumor activity. The hepatocyte growth factor receptor (MET) was targeted in untreated patients in a phase III trial with MoAb rilotumumab, with or without $\mathrm{CT}$, but the study was stopped because of mortality excess in the rilotumumab arm. Mammalian target of rapamycin (MTOR) pathway
\end{abstract}

Felice Pasini

felicepasini@excite.com

1 Department of Medical Oncology, Ospedale S. Maria della Misericordia, Viale Tre Martiri, 140-45100 Rovigo, Italy

2 Medical Oncology Unit, Casa di Cura Pederzoli, Peschiera del Garda, Verona, Italy

3 General and Upper GI Surgery Division, University of Verona, Verona, Italy inhibition with everolimus was tested in pretreated patients in a placebo-controlled phase III trial who failed to improve OS (5.4 vs. 4.3 months). In conclusion, considering the modest survival gain obtained overall, the high cost of these therapies and the quality of life issue must be primarily considered in treating these patients.

Keywords Gastroesophageal junction adenocarcinoma . Advanced disease $\cdot$ Targeted therapies

\section{Introduction}

In metastatic adenocarcinoma of the gastroesophageal junction (GEJA) chemotherapy has long been considered the cornerstone treatment; nevertheless, studies devoted to this subset are lacking because these patients were enrolled in gastric cancer (GC) trials that were statistically unpowered to examine the two entities separately. In randomized clinical trials of GC, GEJA represented 13-29\% of the study population and the 2-year survival rate did not exceed $20 \%$ [1]. Anyway, EJGA should be considered a distinct entity from non-cardia GC. The higher incidence of EJGA in Western countries confirms that GEJA and noncardia GC are related to risk factors having different distributions across the world. Gastroesophageal reflux and Barret metaplasia are risk factors for EJGA [2], while gastric atrophia due to Helicobacter pylori infection is the main risk factor for non-cardia GC. From the clinicopathological point of view, GEJA demonstrated a higher aggressiveness compared to non-cardia GC, more advanced TNM stage, younger age, higher recurrence rate and lower survival rates [3-5].

Some studies report that mutations and copy number alterations differ between GEJA and non-cardia GC. 
Tumors with chromosomal instability, marked aneuploidy and amplification of receptor tyrosine kinases showed elevated frequency in the gastroesophageal junction. TP53 and RAS mutations were also most frequent in GEJA, while tumors arising from the mid and distal stomach were more likely to have PIK3CA, RHOA and Wnt pathway mutations, microsatellite instability (MSI) and positivity for Epstein-Barr virus [5, 6]. Another strategy for molecular classification is based on the gene expression profile. One study used gene expression data and found different clinical outcomes in relation to four different patterns of molecular alterations. The mesenchymal-like type had the worst prognosis; the MSI group had the best overall prognosis, while the TP53-active and TP53-inactive groups presented an intermediate prognosis. The TP53-active subtype was most frequently found in GEJA [7]. Another study identified 511 genes with dysregulated expression in cardia or non-cardia GC; of these genes, about one-half were dysregulated in both cardia and non-cardia, onefourth in cardia and one-fourth in non-cardia only. Some genes were associated with survival; the most significant $P$ values were documented for ALDH3A1 and TRIP13 genes in GEJA, while ADA, ADH1, AKR1B10, ATP4B, LHFP, TFF2 and LIPF genes in non-cardia cancer [8]. Amplification of the HER2 gene is found in about 15-20\% of the patients and seems associated with a negative prognostic role; higher expression was documented in the GEJ $(33.2 \%)$ and proximal part compared to distal parts of the stomach [9].

A recent report from a German database on GEJA and GC for the years 2006-2009 showed that monotherapy, doublet and triplet chemotherapies were used in about 10 , 60 and $30 \%$ of the patients, respectively; older or less fit patients were more likely to receive monotherapy or doublets, while younger patients more commonly received triplets (40.2 vs. $20.8 \%)$. Consistent with other reports, median age was 67 years with male preponderance (64\%). This analysis reflects the transfer of study data into clinical practice, although the impact on survival was not investigated [10]. Over the years, an increasing number of targeting agents has become available for many types of tumors, and these were also tested in GC and GEJA. In this review, we summarize the results of clinical studies testing targeted therapies in GEJA by separately analyzing targeted oncogenic pathways (Fig. 1).

\section{Targeting the epidermal growth factor family}

The epidermal growth factor receptor (EGFR) family is composed of four members: HER1 (also known as EGFR/ ErbB1), HER2, HER3 (also named ErbB-3) and HER4 (also termed ErbB-4). These receptors share the same molecular structure with an extracellular ligand-binding domain, a short transmembrane domain and an intracellular domain with tyrosin kinase (TK) activity (except the HER3). The binding of different ligands to the extracellular domain triggers a signal transduction cascade that can influence many aspects of tumor cell biology, including cell proliferation, apoptosis, adhesion, migration and differentiation. Ligand binding induces EGFR homodimerization as well as heterodimerization with other types of HER proteins. GFR signaling can be deregulated in cancer by various mechanisms (i.e., increased receptor expression, autocrine or paracrine ligand secretion and somatic mutations). In contrast to colorectal and lung cancer, KRAS mutation status and EGFR mutations do not seem to play a relevant role.

Clinical strategies have been developed to target GFR in gastrointestinal cancers such as:

1. Monoclonal antibody (moAb) binding epitopes of the extracellular domain of GFR;

2. MoAbs devoted to neutralizing ligands [i.e., vascular endothelial growth factor (VEGF)];

3. Small molecules that cross the cell membrane and interfere with the enzymatic function of TK receptor or intracellular signaling molecules able to inhibit aberrant signal transduction.

(a) The EGFR (HER1/EGFR/ErbB1) is a cell surface protein that binds to epidermal growth factor. Binding of the protein to the ligand induces receptor dimerization and tyrosine autophosphorylation leading to cell proliferation. EGFR is approximately expressed by immunohistochemistry (IHC) in 30-70\% of esophageal adenocarcinomas (ADs) and may correlate with a dismal survival. EGFR inhibition was attempted using moAbs cetuximab, panitumumab, matuzumab and nimotuzumab, and the results were reported in several phase I-II studies (Table 1) [11-22].

The AGITG ATTAX3 study [21], a randomized phase II study, compared chemotherapy (weekly docetaxel, cisplatin and fluoropyrimidine) with and without panitumumab. The addition of panitumumab to docetaxel-based chemotherapy did not improve efficacy, but increased some G3/4 toxicities. A safety alert from the REAL-3 study [23] prompted an unplanned review of the data; although no evidence of adverse outcomes was detected in the experimental arm, the study was stopped after enrolling 77 patients (38 with panitumumab).

A randomized phase II trial [22] evaluated nimotuzumab in association with irinotecan versus irinotecan in secondline therapy; the primary end point (PFS) was not met, but the combination showed potential outcome improvement in the EGFR $2+/ 3+$ subset. On the whole, data from phase II showed modest survival gain; nevertheless panitumumab 


\section{LYMPHOCYTE T}

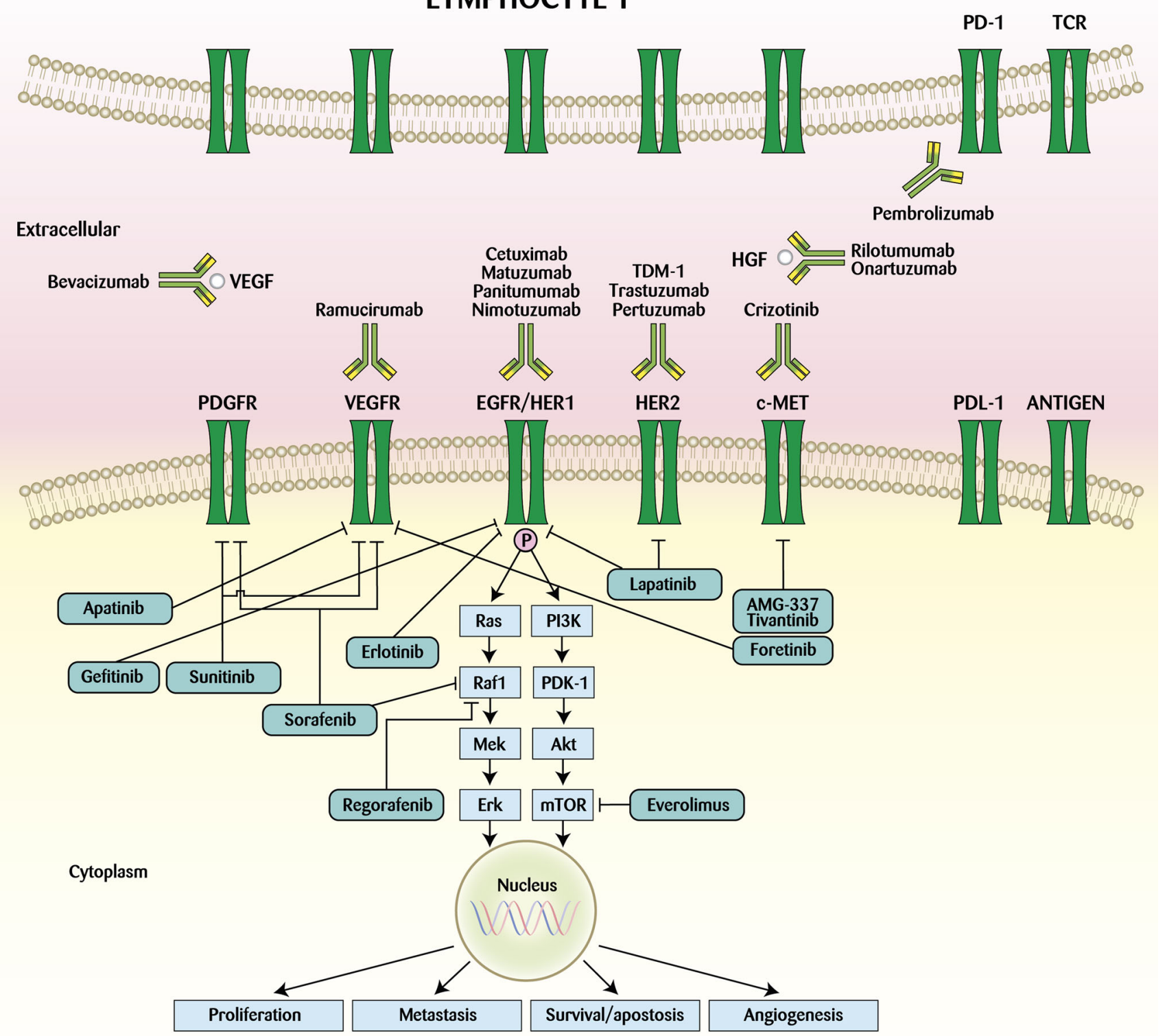

\section{TUMOR CELL}

Fig. 1 Targeted oncogenic pathways in advanced gastroesophageal adenocarcinoma

and cetuximab underwent evaluation in the REAL-3 [23] and EXPAND [24] phase III randomized clinical trials (Table 2). A nimotuzumab phase III study is ongoing in recurrent Asian patients overexpressing EGFR $2+/ 3+$ in IHC. The REAL-3 trial [23] compared a standard EOX regimen (epirubicin, oxaliplatin, capecitabine) with a modified EOX (mEOX) associated with panitumumab; indeed, the panitumumab arm was detrimental in terms of OS, which was the primary end point.

In an exploratory analysis of 276 patients receiving panitumumab, the development of any grade of rash (79\% of the patients) was associated with significantly longer OS and PFS: median OS was 10.3 vs. 4.3 months and median PFS was 6.8 vs. 3.7 months in patients with or without rash, respectively $(p<0.0001)$. Negative results were also obtained in the EXPAND trial [24], which tested the combination of capecitabine and cisplatin with or without cetuximab. The addition of cetuximab failed to improve the PFS (the primary end point), OS and response rate (RR). In a predefined subset analysis, irrespective of the treatment arm, patients with HER2-negative tumor (535 patients) showed increased risk of death (HR 1.55, $95 \%$ CI 1.24-1.94) and reduced RR (HR 0.47, $95 \%$ CI 0.31-0.72) compared with patients with HER2-positive tumors (144 
Table 1 Phase I-II studies with anti-EGFR moAbs

\begin{tabular}{|c|c|c|c|c|c|}
\hline Ref. & Patients & Setting & Population & Therapy & Outcome \\
\hline Pinto et al. [11] & 72 & $\begin{array}{l}\text { Metastatic } \\
\text { 1st line }\end{array}$ & Gastric and GEJ AD (18\%) & $\begin{array}{l}\text { Cetuximab }+ \text { Cisplatin and } \\
\text { docetaxel }\end{array}$ & $\begin{array}{l}\mathrm{RR}=41 \% \\
\mathrm{mTTP}=5 \mathrm{mo} \\
\mathrm{mOS}=9 \mathrm{mo}\end{array}$ \\
\hline Pinto et al. [12] & 38 & $\begin{array}{l}\text { Metastatic } \\
1 \text { st line }\end{array}$ & Gastric and GEJ AD (10.5\%) & Cetuximab + FOLFIRI & $\begin{array}{l}\mathrm{RR}=44 \% \\
\mathrm{mTTP}=8 \mathrm{mo} \\
\mathrm{mOS}=16 \mathrm{mo}\end{array}$ \\
\hline Gold et al. [13] & 63 & $\begin{array}{l}\text { Metastatic } \\
\text { 2nd line }\end{array}$ & Esophageal AD & Cetuximab & $\begin{array}{c}\mathrm{RR}=5 \% \\
\mathrm{mPFS}=1.8 \mathrm{mo} \\
\mathrm{mOS}=4 \mathrm{mo}\end{array}$ \\
\hline Chan et al. [14] & 35 & $\begin{array}{l}\text { Metastatic } \\
\text { 2nd line }\end{array}$ & $\begin{array}{l}\text { Gastric, Esophageal AD (34 \%), } \\
\text { GEJ AD }(23 \%)\end{array}$ & Cetuximab & $\begin{array}{l}\mathrm{RR}=3 \% \\
\mathrm{mPFS}=1.6 \mathrm{mo} \\
\mathrm{mOS}=3\end{array}$ \\
\hline Kim et al. [15] & 44 & $\begin{array}{l}\text { Metastatic } \\
\text { 1st line }\end{array}$ & Gastric and GEJ AD & Cetuximab + XELOX & $\begin{array}{l}\mathrm{RR}=52 \% \\
\mathrm{mPFS}=6.5 \mathrm{mo} \\
\mathrm{mOS}=11.8 \mathrm{mo}\end{array}$ \\
\hline $\begin{array}{l}\text { Lordick et al. } \\
\text { [16] }\end{array}$ & 52 & $\begin{array}{l}\text { Metastatic } \\
1 \text { st line }\end{array}$ & Gastric and GEJ AD (48 \%) & Cetuximab + FUFOX & $\begin{array}{l}\mathrm{RR}=65 \% \\
\mathrm{mTTP}=7.6 \mathrm{mo} \\
\mathrm{mOS}=9.5 \mathrm{mo}\end{array}$ \\
\hline $\begin{array}{l}\text { Moehler et al. } \\
\text { [17] }\end{array}$ & 49 & $\begin{array}{l}\text { Metastatic } \\
\text { 1st line }\end{array}$ & Gastric and GEJ AD (29 \%) & Cetuximab + FI & $\begin{array}{l}\mathrm{RR}=46 \% \\
\mathrm{mPFS}=9 \mathrm{mo} \\
\mathrm{mOS}=16.5 \mathrm{mo}\end{array}$ \\
\hline Rao et al. [18] & 35 & $\begin{array}{l}\text { Metastatic } \\
\text { 1st line } \\
\text { randomized } \\
\text { Phase II }\end{array}$ & Gastric and GEJ AD (60\%) & Matuzumab + ECX & $\begin{array}{l}\mathrm{RR}=31 \% \\
\mathrm{mPFS}=4.8 \mathrm{mo} \\
\mathrm{mOS}=9.4 \mathrm{mo}\end{array}$ \\
\hline $\begin{array}{l}\text { Trarbach et al. } \\
\text { [19] }\end{array}$ & 15 & $\begin{array}{r}\text { Metastatic/ } \\
\text { recurrent }\end{array}$ & Gastric and GEJ AD (27 \%) & Matuzumab + PLF & $\mathrm{RR}=27 \%$ \\
\hline $\begin{array}{l}\text { Schoennemann } \\
\text { et al. [20] }\end{array}$ & 50 & $\begin{array}{r}\text { Metastatic/ } \\
\text { recurrent }\end{array}$ & Gastric and GEJ AD (86 \%) & Cetuximab + irinotecan & $\begin{array}{l}\mathrm{RR}=14 \% \\
\mathrm{mPFS}=3.3 \mathrm{mo} \\
\mathrm{mOS}=5.5 \mathrm{mo}\end{array}$ \\
\hline $\begin{array}{l}\text { Tebbutt et al. } \\
\text { [21] }\end{array}$ & 38 & $\begin{array}{l}\text { Metastatic } \\
\text { 1st line } \\
\text { randomized } \\
\text { Phase II }\end{array}$ & $\begin{array}{l}\text { Gastric and GEJ AD (\% not } \\
\text { reported) } 10 \% \mathrm{SCC}\end{array}$ & $\begin{array}{l}\text { Panitumumab }+ \text { docetaxel, } \\
\text { cisplatin, fluoropyrimidine }\end{array}$ & $\begin{array}{l}\mathrm{RR}=58 \% \\
\mathrm{mPFS}=6.0 \mathrm{mo} \\
\mathrm{mOS}=10.0 \mathrm{mo}\end{array}$ \\
\hline Satoh et al. [22] & 83 & $\begin{array}{l}\text { Metastatic } \\
\text { 2nd line } \\
\text { randomized } \\
\text { Phase II }\end{array}$ & Gastric and GEJ AD (10.4\%) & Irinotecan + nimotuzumab & $\begin{array}{l}\mathrm{RR}=18.4 \% \\
\mathrm{mPFS}=2.4 \mathrm{mo} \\
\mathrm{mOS}=8.3 \mathrm{mo}\end{array}$ \\
\hline
\end{tabular}

$E G F R$ epidermal growth factor receptor, moAbs monoclonal antibodies, $A D$ adenocarcinoma, $G E J$ gastroesophageal junction, $S C C$ squamous cell carcinoma, $R R$ response rate, $m T T P$ median time to progression, $m O S$ median overall survival, $m P F S$ median progression-free survival, FOLFIRI leucovorin, fluorouracil, irinotecan, XELOX capecitabine and oxaliplatin, FUFOX leucovorin, fluorouracil and oxaliplatin, FI irinotecan, folinic acid and fluorouracile, ECX epirubicin, cisplatin and capecitabine, $P L F$ fluorouracil, leucovorin and cisplatin, $m o$ months

patients). Tumor EGFR expression was generally low; however, using a series of cutoff points from an IHC score, there was a tendency for improved OS, PFS and RR when adding cetuximab to $\mathrm{CT}$ in patients with high tumor EGFR IHC scores. This finding suggests a benefit from adding cetuximab to CT in a small proportion of patients with high EGFR tumor expression [25]. (b) The clinical role of HER2 overexpression was been first evaluated in the ToGA trial [26]. The study enrolled 594 patients (about $18 \%$ with GEJA) and compared cisplatin-fluoropyrimidine chemotherapy alone or with trastuzumab with OS as the primary endpoint. All patients had immunohistochemical overexpression of HER2 or gene amplification by FISH. Among the screened tumors, HER2 
Table 2 Phase III randomized clinical trials targeting EGFR

\begin{tabular}{|c|c|c|c|c|c|c|}
\hline Ref. & Patients & Setting & $\begin{array}{l}\text { Primary end } \\
\text { point }\end{array}$ & Population & Therapy & Outcome \\
\hline $\begin{array}{l}\text { Waddel et al. } \\
\text { [23] }\end{array}$ & 553 & $\begin{array}{l}\text { Metastatic } \\
\text { 1st line }\end{array}$ & OS & $\begin{array}{l}\text { Gastric and GEJ AD } \\
(34 \%)\end{array}$ & $\begin{array}{l}\text { Panitumumab }+ \text { mEOX vs. } \\
\text { standard EOX }\end{array}$ & $\begin{array}{l}\mathrm{RR}=42 \text { vs. } 46 \% \\
\mathrm{mPFS}=6 \text { vs. } 7.4 \mathrm{mo} \\
\quad(p=0.068) \\
\text { mOS }=8.8 \text { vs. } 11 \mathrm{mo} \\
\quad(p=0.01)\end{array}$ \\
\hline $\begin{array}{l}\text { Lordick et al. } \\
\text { [24] }\end{array}$ & 904 & $\begin{array}{l}\text { Metastatic } \\
\text { 1st line }\end{array}$ & PFS & $\begin{array}{l}\text { Gastric and GEJ AD } \\
(16 \%)\end{array}$ & $\begin{array}{l}\text { Cetuximab } \pm \text { capecitabine and } \\
\text { cisplatin }\end{array}$ & $\begin{array}{l}\mathrm{RR}=30 \text { vs. } 29 \% \\
\mathrm{mPFS}=4.4 \text { vs. } 5.9 \mathrm{mo} \\
\mathrm{mOS}=9.4 \text { vs. } 10.7 \mathrm{mo}\end{array}$ \\
\hline
\end{tabular}

EOX epirubicin, oxaliplatin and capecitabine, $m o$ months, $m E O X$ modified epirubicin, oxaliplatin and capecitabine

Table 3 Phase III randomized clinical trials targeting HER2

\begin{tabular}{|c|c|c|c|c|c|c|}
\hline Ref. & Patients & Setting & $\begin{array}{l}\text { Primary } \\
\text { end point }\end{array}$ & Population & Therapy & Outcome \\
\hline Bang et al. [26] & 594 & $\begin{array}{l}\text { Metastatic } \\
\text { 1st line }\end{array}$ & OS & Gastric and GEJ AD (18\%) & $\begin{array}{l}\text { Trastuzumab } \pm \\
\text { fluoropyrimidine } \\
\text { and cisplatin }\end{array}$ & $\begin{array}{l}\mathrm{RR}=47 \text { vs. } 35 \% \\
\mathrm{mPFS}=6.7 \text { vs. } 5.5 \mathrm{mo} \\
\mathrm{mOS}=13.8 \text { vs. } 11.1 \mathrm{mo}\end{array}$ \\
\hline Hecht et al. [27] & 545 & $\begin{array}{l}\text { Metastatic } \\
\text { 1st line }\end{array}$ & OS & $\begin{array}{l}\text { Gastric, Esophageal (5\%) } \\
\text { and GEJ AD }(9 \%)\end{array}$ & Lapatinib \pm capeOx & $\begin{array}{l}\mathrm{RR}=53 \text { vs. } 40 \% \\
\mathrm{mPFS}=6 \text { vs. } 5.4 \mathrm{mo} \\
\mathrm{mOS}=12.2 \text { vs. } 10.5 \mathrm{mo}\end{array}$ \\
\hline Satoh et al. [28] & 261 & $\begin{array}{l}\text { Metastatic } \\
\text { 2nd line } \\
\text { phase II-III }\end{array}$ & OS & Gastric & Lapatinib \pm paclitaxel & $\begin{array}{l}\mathrm{RR}=27 \text { vs. } 9 \% \\
\mathrm{mPFS}=5.4 \text { vs. } 4.4 \mathrm{mo} \\
\mathrm{mOS}=11 \text { vs. } 8.9 \mathrm{mo}\end{array}$ \\
\hline Kang [29] & 415 & $\begin{array}{l}\text { Metastatic } \\
\text { 2nd line }\end{array}$ & OS & Gastric and GEJ AD (\% NR) & TDM-1 vs. paclitaxel & $\begin{array}{l}\mathrm{RR}=21 \text { vs. } 20 \% \\
\mathrm{mPFS}=2.7 \text { vs. } 2.9 \mathrm{mo} \\
\mathrm{mOS}=7.9 \text { vs. } 8.6 \mathrm{mo}\end{array}$ \\
\hline
\end{tabular}

CapeOx capecitabine and oxaliplatin, mo months, $N R$ not reported

overexpression was positive in $21 \%$ of gastric carcinomas and in $33 \%$ of GEJA. The cohort receiving trastuzumab had a significant improvement in OS (13.8 vs. 11.1 months, HR 0.74, $95 \%$ CI 0.6-0.91, $p=0.0046$ ), PFS (6.7 vs. 5.5 months) and RR (47 vs. $35 \%)(p=0.0017)$. In an explorative analysis, patients with strongly HER2-positive tumors derived the greatest OS benefit with the addition of trastuzumab (16.0 vs. 11.8 months, HR 0.68, $95 \%$ CI 0.5-0.83). Based on these data, trastuzumab was approved, in combination with cisplatin and a fluoropyrimidine, for first-line treatment of metastatic HER2-overexpressing gastric or GEJA (Table 3).

Lapatinib ditosylate is a dual anti-EGFR and anti-HER2 TK. This oral drug was investigated in the LOGIC [27] and TyTAN [28] trials. In the LOGIC study, the primary efficacy population (PEP) comprised all subjects with centrally confirmed tumor FISH amplification. Patients were randomized to CapeOx with or without lapatinib. The study failed to meet its primary endpoint (i.e., OS of PEP); mOS and mPFS were 12.2 vs. 10.5 months, 6.0 vs. 5.4 months in the experimental arm and control arm, respectively. Prespecified subset analyses showed significant OS improvements in patients who were Asian $(\mathrm{HR}=0.68)$ and under 60 years $(H R=0.69)$. There was no association between IHC and OS. In patients treated with lapatinib, the toxicity profile showed increased skin toxicity and grade $3+$ diarrhea (12 vs. $3 \%$ ). Based on these negative results, lapatinib is not recommended outside clinical trials. The TyTAN study [28] was conducted in Asian HER2 FISH-amplified patients comparing lapatinib in association with paclitaxel or not in second-line treatment; OS was not different in the two arms. However, lapatinib produced OS and PFS improvement in the small subsets of Chinese patients and those with $\mathrm{IHC} 3+$.

T-DM1 is a conjugate of the MoAb trastuzumab and a chemotherapy drug, called emtansine; after binding to 
Table 4 Phase II studies with TKI (erlotinib, gefitinib)

\begin{tabular}{|c|c|c|c|c|c|}
\hline Ref. & Patients & Setting & Population & Therapy & Outcome \\
\hline Wainberg et al. [31] & 33 & $\begin{array}{l}\text { Metastatic } \\
\text { 1st line }\end{array}$ & Gastric and esophageal AD & Erlotinib + FOLFOX 6 & $\begin{array}{l}\mathrm{RR}=51.5 \% \\
\mathrm{mPFS}=5.5 \mathrm{mo} \\
\mathrm{mOS}=11 \mathrm{mo}\end{array}$ \\
\hline Dragovich et al. [32] & 70 & $\begin{array}{l}\text { Metastatic } \\
\text { 1st line }\end{array}$ & Gastric and GEJ AD & Erlotinib & $\mathrm{RR}=9 \%$ \\
\hline Ilson et al. [33] & 30 & $\begin{array}{l}\text { Metastatic } \\
\text { 2nd line }\end{array}$ & Esophageal and GEJ AD and SCC & Erlotinib & $\mathrm{RR}=8 \%$ \\
\hline $\begin{array}{l}\text { Adelstein et } \\
\text { al [34] }\end{array}$ & 58 & $\begin{array}{l}\text { Metastatic } \\
\text { 1st/2nd line }\end{array}$ & Esophageal and GEJ AD and SCC & Gefitinib & $\begin{array}{l}\mathrm{RR}=7 \% \\
\mathrm{mOS}=5.5 \mathrm{mo}\end{array}$ \\
\hline Ferry et al. [35] & 27 & Inoperable 1st line & Esophageal AD & Gefitinib & $\begin{array}{l}\mathrm{RR}=11 \% \\
\mathrm{mOS}=4.5 \mathrm{mo} \\
\mathrm{mPFS}=1.9 \mathrm{mo}\end{array}$ \\
\hline
\end{tabular}

FOLFOX 5-fluorouracil, leucovorin and oxaliplatin, mo months

HER2 receptor on the tumor cell membrane, it delivers the drug to the cytoplasm. The GATSBY study [29] compared TDM-1 vs. paclitaxel single agent in second-line therapy; the primary end point, i.e., OS, was not met, although grade 3 adverse events were lower in the experimental arm (70 vs. $60 \%$ ). Dual HER2 inhibition is currently under investigation in the JACOB phase III study randomizing cisplatin fluoropyrimidine chemotherapy combined with trastuzumab with or without pertuzumab [30].

(c) The small-molecule tyrosine kinase inhibitors (TKI), erlotinib and gefitinib, were also tested as single agent or in combination with chemotherapy (Table 4). Gefitinib and erlotinib specifically target the EGFR tyrosine kinase by binding in a reversible fashion to the adenosine triphosphate (ATP) binding site of the receptor to form a homodimer. By inhibiting the ATP, formation of phosphotyrosine residues in EGFR is not possible, and the signal cascades are not initiated.

Stable disease and RR generally were in the magnitude of $10 \%$, except in one trial [31]. One trial suggested that GEJAs were more likely to respond to erlotinib than gastric cancers [32]; in another trial, responses were seen almost exclusively in SCC as compared to AD [33]. A possible explanation is that KRAS and EGFR mutations are uncommon [31-35] and thus not predictive of response to TKI in esophageal cancer. In conclusion, the results were very modest at best for these agents in a metastatic setting.

\section{Targeting angiogenesis}

Aberrant tumor angiogenesis has been considered a potential target in cancer therapy. Currently, there are no validated biomarkers to select patients for antiangiogenic therapy, although some candidate surrogate markers of bevacizumab response have been described. Tumor VEGF expression was identified as a poor prognosis marker in esophageal cancer [36]. Strategies developed to modulate angiogenic signaling were: (1) targeting proangiogenic factors with moAbs (i.e., the anti-VEGF moAb bevacizumab); (2) targeting angiogenic receptors with moAbs (i.e., the moAb ramucirumab); (3) targeting angiogenic receptors with TKI (i.e., sunitinib, sorafenib) Table 5.

\section{Depletion of proangiogenic factors}

Bevacizumab is a moAb anti-VEGF-A, a protein playing a significant role in angiogenesis. The drug was tested in the AVAGAST phase III trial [37], which enrolled 774 patients (14\% GEJA) and compared the combination of cisplatin fluoropyrimidine with and without bevacizumab in firstline treatment. The trial failed to meet the primary endpoint (OS); subgroup analysis for GEJA was also consistent with the overall result of the study.

Median OS was 10.1 and 12.1 months in the control and bevacizumab subsets, respectively ( $\operatorname{HR} 0.87, p=0.1)$; on the other hand, there was a significant improvement in PFS (5.3 vs. $6.7 \mathrm{mo}$ ) and RR (37 vs. $46 \%$ ) in the experimental arm. The bevacizumab safety profile was as expected, with increased rates of hypertension (6.2 vs. $0.5 \%)$ and gastrointestinal perforation $(2.3$ vs. $0.3 \%)$. Traslational research [38] evaluated the efficacy of bevacizumab with a comprehensive prospective biomarker analysis. High plasma VEGF-A levels and low neuroplin-1 expression were negative prognostic factors, although these patients were more likely to respond to bevacizumab. Consequently, plasma VEGF-A and tumor neuropilin-1 seem potential biomarker candidates for predicting clinical outcome; however, the finding needs confirmation in prospective studies. In a recent phase II study, 39 patients 
Table 5 Phase II studies targeting angiogenesis with TKI (sunitinib, sorafenib, regorafenib, apatinib)

\begin{tabular}{|c|c|c|c|c|c|}
\hline Ref. & Patients & Setting & Population & Therapy & Outcome \\
\hline $\begin{array}{l}\text { Moehler MH et al. } \\
\text { [49] }\end{array}$ & $\begin{array}{l}91 \text { (45 sunitinib) } \\
\text { Randomized phase II }\end{array}$ & $\begin{array}{l}\text { Metastatic } \\
\text { 2nd/3rd line }\end{array}$ & $\begin{array}{l}\text { Gastric and GEJ AD } \\
(50 \%)\end{array}$ & Sunitinib \pm FOLFIRI & $\begin{array}{l}\mathrm{RR}=20 \% \\
\mathrm{mPFS}=3.6 \mathrm{mo} \\
\mathrm{mOS}=10.5 \mathrm{mo}\end{array}$ \\
\hline Bang et al. [50] & 78 & $\begin{array}{l}\text { Metastatic } \\
\text { 2nd line }\end{array}$ & $\begin{array}{l}\text { Gastric and GEJ AD } \\
(6.4 \%)\end{array}$ & Sunitinib & $\begin{array}{l}\mathrm{RR}=2.6 \% \\
\mathrm{mPFS}=2.3 \mathrm{mo} \\
\mathrm{mOS}=6.8 \mathrm{mo}\end{array}$ \\
\hline $\begin{array}{l}\text { Moehler M et al. } \\
\text { [51] }\end{array}$ & 51 & $\begin{array}{l}\text { Metastatic } \\
\text { 2nd line }\end{array}$ & $\begin{array}{l}\text { Gastric and GEJ AD } \\
(22 \%)\end{array}$ & Sunitinib & $\begin{array}{l}\mathrm{RR}=3.9 \% \\
\mathrm{mPFS}=1.3 \mathrm{mo} \\
\mathrm{mOS}=5.8 \mathrm{mo}\end{array}$ \\
\hline $\begin{array}{l}\text { Martin-Richard } \\
\text { et al. [52] }\end{array}$ & 40 & $\begin{array}{l}\text { Metastatic } \\
\text { 2nd line }\end{array}$ & $\begin{array}{l}\text { Gastric and GEJ AD } \\
(27.5 \%)\end{array}$ & $\begin{array}{r}\text { Sorafenib }+ \\
\text { oxaliplatin }\end{array}$ & $\begin{array}{l}\mathrm{RR}=2.5 \% \\
\mathrm{mPFS}=3 \mathrm{mo} \\
\mathrm{mOS}=6.5 \mathrm{mo}\end{array}$ \\
\hline Sun et al. [53] & 44 & $\begin{array}{l}\text { Metastatic } \\
\text { 1st line }\end{array}$ & $\begin{array}{l}\text { Gastric and GEJ AD (\% } \\
\text { not reported) }\end{array}$ & $\begin{array}{l}\text { Sorafenib }+ \\
\text { docetaxel/cisplatin }\end{array}$ & $\begin{array}{l}\mathrm{RR}=41 \% \\
\mathrm{mPFS}=5.8 \mathrm{mo} \\
\mathrm{mOS}=13.6 \mathrm{mo}\end{array}$ \\
\hline $\begin{array}{l}\text { Pavlakis et al. } \\
\text { [54] }\end{array}$ & $\begin{array}{l}152 \\
\text { Randomized phase II }\end{array}$ & $\begin{array}{l}\text { Metastatic } \\
\text { 2nd-3rd line }\end{array}$ & $\begin{array}{l}\text { Gastric and GEJ AD } \\
(37 \%)\end{array}$ & $\begin{array}{l}\text { Regorafenib vs. } \\
\text { placebo }\end{array}$ & $\begin{array}{l}\mathrm{RR}=\mathrm{NR} \text { vs. NR } \\
\mathrm{mPFS}=11.1 \mathrm{vs} . \\
3.9 \mathrm{wks} \\
\mathrm{mOS}=25 \mathrm{vs} . \\
19.4 \mathrm{wks}\end{array}$ \\
\hline Li et al. [56] & $\begin{array}{l}273 \\
\text { Randomized phase III }\end{array}$ & $\begin{array}{l}\text { Metastatic after } \\
\text { 2nd line }\end{array}$ & $\begin{array}{l}\text { Gastric and GEJ AD } \\
(22 \%)\end{array}$ & Apatinib vs. placebo & $\begin{array}{l}\mathrm{RR}=2.8 \mathrm{vs} .0 \% \\
\mathrm{mPFS}=2.6 \mathrm{vs} . \\
1.8 \mathrm{mo} \\
\mathrm{mOS}=6.5 \mathrm{vs} . \\
4.7 \mathrm{mo}\end{array}$ \\
\hline
\end{tabular}

mo months, $N R$ not reported, wks weeks

(66\% distal esophageal and GEJ adenocarcinoma) received bevacizumab with a modified FOLFOX regimen. RR was $56 \%$, mTTP 8.2 months and mOS 15.2 months; $12.8 \%$ of deep venous thromboembolism and pulmonary embolism was reported [39]. A phase Ib/II study, testing weekly docetaxel and cisplatin together with capecitabine and bevacizumab, was closed early, after the accrual of 22 patients because of the accumulation of toxicity-related deaths [40].

\section{Targeting angiogenic receptors with moAbs}

Ramucirumab is a human IgG1 moAb VEGF-receptor 2 antagonist. The REGARD [41] and RAINBOW [42] randomized phase III clinical trials tested the efficacy of ramucirumab in advanced/metastatic pretreated gastric or GEJA patients with ECOG PS $=0-1$; OS, the primary end point, was met in both studies. In the REGARD trial [41], 355 patients (25\% GEJA) were randomized (2:1) to receive ramucirumab or placebo. In the ramucirumab arm, median OS was 5.2 vs. 3.8 months (HR 0.78, $95 \%$ CI,
$0.60-0.99 ; p=0.047)$, median PFS was 2.1 vs. 1.3 months (HR $0.48, p<0.0001$ ), and the disease control rate was 49 vs. $23 \%(p<0.0001)$. In the subgroup analysis for GEJA, significance was maintained only for PFS (HR 0.39, $95 \%$ CI 0.23-0.65) and not for OS. While rates of adverse events were mostly similar between groups, rates of hypertension were higher in ramucirumab-treated patients (16 vs. $8 \%$ ). Outcome and toxicity profiles were similar in patients $\leq 65$ years or older [43]. Ramucirumab has been approved by FDA as a single agent for the treatment of patients with advanced or metastatic, gastric or GEJA progressing on or after prior fluoropyrimidine-or platinum containing chemotherapy Table 6 .

In the RAINBOW study [42], 665 patients were randomized (1:1) to paclitaxel with or without ramucirumab. In the ramucirumab arm median OS was 9.6 vs. 7.4 months (HR 0.81, $95 \%$ CI 0.67-0.96; $p=0.017$ ), median PFS was 4.4 vs. 2.9 months (HR $0.63,95 \%$ CI $0.54-0.75$; $p<0.0001)$, and RR was 28 vs. $16 \%(p=0.0001)$. At multivariate analysis, factors significantly associated with OS were geographical region, ECOG PS, weight loss, 
number of metastatic sites, presence of ascites, tumor differentiation and prior gastrectomy. The HR for OS improved after adjusting for these factors (HR 0.745, $95 \%$ CI $0.62-0.88 ; p=0.001$ ) [44]. With the addition of ramucirumab, QoL was maintained for a longer time, and more patients reported stable or improved scores [45]. Outcome was similar in Western and Japanese populations, with a prolonged post-progression survival in Japanese patients (5.8 vs. 4.4 months), probably due to higher use of post-discontinuation treatment [46].

Preliminary pharmacokinetic data from patients enrolled in the REGARD and RAINBOW trials found an association of longer PFS, OS, improved HR and increased toxicity with higher ramucirumab exposures [47]. To validate this finding, a phase II randomized trial is investigating the pharmacokinetics and safety of different ramucirumab doses in second-line patients (ClinicalTrials.gov Identifier: NCT 02443883).

A randomized phase II study, enrolling 168 patients (84 in the ramucirumab arm), GEJA $31 \%$, compared modified FOLFOX6 plus ramucirumab vs. placebo; mPFS, the primary end point, was 6.4 vs. 6.7 months and OS 11.7 vs. 11.5 months in the experimental and control arm, respectively. PFS and OS were not influenced by the primary tumor location (esophageal vs. gastric/GEJ), and the disease control rate was higher in the ramucirumab arm ( 85 vs. $67 \%, p=0.008$ ) [48]. The ongoing RAINFALL placebo-controlled phase III trial compares capecitabine and cisplatin with or without ramucirumab in first-line therapy in patients with metastatic gastric or GEJ AD with PFS as primary end point (ClinicalTrials.gov Identifier: NCT 02314117).

\section{Targeting angiogenic receptors with TKI}

Sorafenib, sunitinib and regorafenib are multitargeted TKIs that inhibit angiogenesis by targeting different signaling pathways. A randomized placebo-controlled multicentric AIO phase II trial compared FOLFIRI with or without sunitinib in pretreated patients. The study failed to meet the primary end point (PFS); biomarker analysis has been planned to identify subgroups potentially benefiting from the addition of sunitinib [49]. Other phase II studies have been conducted mostly in second line, showing modest activity: mPFS in the range of 1.3-3.6 months and OS of about 7 months [50-52]. In front-line therapy, sorafenib in combination with chemotherapy provided a $41 \% \mathrm{RR}$ (primary end point) [53]. The randomized phase II INTEGRATE trial documented a statistically improved PFS with regorafenib in respect to placebo, but only a trend for OS [54]. Regional differences were found in the magnitude of effect, but regorafenib was effective in all regions and subsets. High plasma levels of IL8, VEGF-A and sVEGFR1 showed no convincing evidence of a relation with adverse prognosis [55]. A broader biomarker study including markers beyond the VEGF axis and tissue-based markers is ongoing (Clinical trial information: ACTRN12612000239864).

Apatinib, a novel vascular endothelial growth factor receptor 2 TKI, was tested vs. placebo in patients with advanced gastric or GEJ AD failing at least two lines of prior chemotherapy in the Chinese population. In this heavily pretreated but highly selected, subset, the study met both the co-primary end points (OS, PFS), without significant differences in QoL [56].

\section{Targeting hepatocyte growth factor receptor (MET)}

MET is a transmembrane TKR for which hepatocyte growth factor (HGF) is the only known ligand. MET activation induces complex cellular signaling mediated through a variety of transduction pathways. Under

Table 6 Studies targeting in mTOR complex

\begin{tabular}{|c|c|c|c|c|c|}
\hline Ref. & Patients & Setting & Population & Therapy & Outcome \\
\hline Doi T et al. [66] & 53 & $\begin{array}{l}\text { Advanced/metastatic } \\
\text { 2nd line } \\
\text { Phase II }\end{array}$ & Gastric and GEJ AD (\% not reported) & Everolimus & $\begin{array}{l}\mathrm{RR}=0 \% \\
\mathrm{DCR}=56 \% \\
\mathrm{mPFS}=2.7 \mathrm{mo} \\
\mathrm{mOS}=10.1 \mathrm{mo}\end{array}$ \\
\hline Ohtsu et al. [67] & 650 & $\begin{array}{l}\text { 2nd-3rd line } \\
\text { Phase III }\end{array}$ & Gastric and GEJ AD (27\%) & Everolimus \pm BSC & $\begin{array}{l}\mathrm{RR}=5 \% \text { vs. } 2 \% \\
\mathrm{DCR}=44 \% \text { vs. } 22 \% \\
\mathrm{mPFS}=1.7 \text { vs. } 1.4 \mathrm{mo} \\
\mathrm{mOS}=5.4 \text { vs. } 4.3 \mathrm{mo}\end{array}$ \\
\hline
\end{tabular}

mo months, $B S C$ best supportive care 
physiological conditions, MET-driven invasive growth is tightly regulated and plays a key role in tissue growth and repair. Aberrant HGF/MET activation occurs in multiple types of malignancies, including GEJA, via several mechanisms including overexpression, focal gene amplification, gene copy number gain, activating mutations, TKR transactivation and autocrine or paracrine signaling.

Dysregulated HGF/MET signaling is commonly seen in GEJA. Approximately $0-10 \%$ of gastric cancers exhibit MET amplification and up to $60 \%$ MET overexpression; both amplification and overexpression have been associated with a more aggressive phenotype and poor prognosis [57-59]. However, quantification of MET overexpression is flawed by the different evaluation criteria used; pathologist training and inter-laboratory quality control are needed for standardization of the results. A phase II randomized study evaluated anti-HGF moAb rilotumumab with or without ECX chemotherapy in 121 non-MET selected naïve patients. Rilotumumab improved OS in MET-high tumors (11.1 vs. 5.7 months, HR $0.29,95 \%$ CI $0.11-0.76, p=0.012$ ). MET-high tumor (42\% of evaluable patients) was defined as weak (1+) or stronger MET IHC staining in $>50 \%$ of malignant cells [60]. The RILOMET-1 phase III study compared ECX with or without rilotumumab in 609 untreated patients with unresectable/advanced gastric/GEJ adenocarcinoma, tumor MET-positive by IHC, HER2 negative. The study was stopped early based on an imbalance in deaths; OS (the primary end point), PFS and ORR were statistically worse in the rilotumumab arm. No subgroups seemed to benefit from rilotumumab, including those with higher percentages of cells with $=1+$ MET expression. Adverse events were higher with rilotumumab: peripheral edema, hypoalbuminemia, deep vein thrombosis and hypocalcemia [61]. The toxicity profile of rilotumumab in combination with cisplatin and capecitabine in Japanese patients with MET-positive gastric/GEJ cancer was consistent with that of Western patients [62]. Crizotinib, tivantinib and foretinib failed to demonstrate significant antitumor activity.

A placebo-controlled phase II study failed to demonstrate PFS improvement with onartuzumab and FOLFOX6 in first-line patients of whom about $33 \%$ were MET positive, irrespective of different MET cutoffs [63]. Due to these negative findings, the phase III study was prematurely stopped after enrolling 562 patients out of the 800 foreseen. OS and PFS were similar in the control and experimental arms (about 11 and 7 months, respectively) [64].Preliminary data reported an encouraging response rate in a phase I study testing AMG 337, an investigational oral MET kinase inhibitor, in MET-amplified patients [65].

\section{Targeting the mammalian target of rapamycin (MTOR) complex}

mTOR is an intracellular serine/threonine kinase that acts in two protein complexes, TORC1 and TORC2 the mammalian target of rapamicin complex. mTOR is involved in multiple pathways regulating cell survival, motility, metabolism and protein synthesis. TORC1 is engaged by the PI3K/AKT signaling pathway, which is frequently deregulated in cancer. Everolimus is an oral drug inhibiting the mTOR pathway. A phase II study in chemotherapypretreated patients reported a disease control rate of $56 \%$ [66] and mOS and mPFS of 10 and 2.7 months, respectively. Everolimus-related pneumonitis (G1-2) was observed in $15 \%$ of the patients. Based on these data, the GRANITE-1, a placebo-controlled phase III study of everolimus in second-/third-line treatment of metastatic GEJA/GC, failed to prolong OS, the primary end point. In the intervention arm, the disease control rate was $43 \%$, and PFS and OS 1.7 and 5.4 months, respectively. Pneumonitis occurred in $3 \%$ of the patients [67].

The ability of everolimus to enhance the activity of second-line treatment with paclitaxel is currently being investigated in another phase III trial, rad001-paclitaxel (RAD-PAC) (AIOSTO-0111, NCT01248403).

\section{Targeting the immune check point pd-1 (programmed death 1)}

Malignant cells may evade the immune system control favoring disease progression. Immune check points (such as CTLA-4 and PD-1 and its ligands) play a key role suppressing T-lymphocyte activity. Reversing the inhibition of adaptive immunity can lead to active stimulation of patient's immune system. Pembrolizumab is a selective $\mathrm{MoAb}$ against PD-1. Preliminary data from the phase I KEYNOTE012 study in heavily pretreated patients showed $31 \%$ RR, with a significant association between the PD-L1 expression level and RR; 6-month OS rate was surprisingly high $(69 \%)$, however at the price of not negligible toxicity $[68,69]$. Based on these results, two phase III studies are ongoing [ClinicalTrials.gov Identifier: NCT02494583 and NCT02370498].

\section{Conclusions}

In unresectable and metastatic GEJA chemotherapy has produced a modest impact on OS [1,70]. The availability of targeted agents gives new hope to the patients on the difficult steep path to the cure of this aggressive tumor, 
although to date only a small survival gain has been shown. Two other major points have to be primarily considered: clinical results must be balanced against the quality of life and quality-adjusted survival and the high cost of these drugs.

\section{Compliance with ethical standards}

Conflict of interest The authors declare that they have no conflict of interest.

Ethical standards This article does not contain any studies with human or animal subjects performed by any of the authors.

\section{References}

1. Pasini F, Fraccon AP, De Manzoni G. The role of chemotherapy in metastatic gastric cancer. Anticancer Res. 2011;31(10):3543-54.

2. Shaheen N, Ransohoff DF. Gastroesophageal reflux, barrett esophagus, and esophageal cancer: scientific review. JAMA. 2002;287:1972-81.

3. Liu K, Zhang W, Chen X, Chen X, Yang K, Zhang B, et al. Comparison on clinicopathological features and prognosis between esophagogastric junctional adenocarcinoma (Siewert II/ III Types) and distal gastric adenocarcinoma: retrospective cohort study, a single institution, high volume experience in China. Medicine (Baltimore). 2015;94(34):e1386.

4. Tajima Y, Yamazaki K, Makino R, Nishino N, Masuda Y, Aoki $\mathrm{S}$, et al. Differences in the histological findings, phenotypic marker expressions and genetic alterations between adenocarcinoma of the gastric cardia and distal stomach. Br J Cancer. 2007;96:631-8.

5. Li-Chang HH, Kasaian K, Ng Y, Lum A, Kong E, Lim H, et al. Retrospective review using targeted deep sequencing reveals mutational differences between gastroesophageal junction and gastric carcinomas. BMC Cancer. 2015;15:32. doi:10.1186/ s12885-015-1021-7.

6. Cancer Genome Atlas Research Network. Comprehensive molecular characterization of gastric adenocarcinoma. Nature. 2014;513(7517):202-9. doi:10.1038/nature13480.

7. Cristescu R, Lee J, Nebozhyn M, Kim K-M, Ting JC, Wong SS, et al. Molecular analysis of gastric cancer identifies subtypes associated with distinct clinical outcomes. Nat Med. 2015;21(5):449-56.

8. Wang $\mathrm{G}, \mathrm{Hu} \mathrm{N}$, Yang $\mathrm{HH}$, Wang $\mathrm{L}, \mathrm{Su} \mathrm{H}$, Clifford R, et al. Comparison of global gene expression of gastric cardia and noncardia cancers from a high-risk population in China. PLoS One. 2013;8(5):e63826. doi:10.1371/journal.pone.0063826.

9. Jørgensen JT. Role of human epidermal growth factor receptor 2 in gastric cancer: biological and pharmacological aspects. World J Gastroenterol. 2014;20(16):4526-35.

10. Hofheinz RD, Al-Batran SE, Ridwelski K, Görg C, Wehle K, Birth $\mathrm{M}$, et al. Population-based patterns of care in the first-line treatment of patients with advanced esophagogastric adenocarcinoma in Germany. Onkologie. 2010;33(10):512-8. doi:10. $1159 / 000319699$.

11. Pinto C, Di Fabio F, Barone C, Siena S, Falcone A, Cascinu S, et al. Phase II study of cetuximab in combination with cisplatin and docetaxel in patients with untreated advanced gastric or gastro-oesophageal junction adenocarcinoma (DOCETUX study). Br J Cancer. 2009;101(8):1261-8. doi:10.1038/sj.bjc. 6605319 .
12. Pinto C, Di Fabio F, Siena S, Cascinu S, Rojas Llimpe FL, et al. Phase II study of cetuximab in combination with FOLFIRI in patients with untreated advanced gastric or gastroesophageal junction adenocarcinoma (FOLCETUX study). Ann Oncol. 2007;18(3):510-7.

13. Gold PJ, Goldman B, Iqbal S, Leichman LP, Zhang W, Lenz HJ, et al. Cetuximab as second-line therapy in patients with metastatic esophageal adenocarcinoma: a phase II Southwest Oncology Group Study (S0415). J Thorac Oncol. 2010;5(9):1472-6. doi:10.1097/JTO.0b013e3181e77a92.

14. Chan JA, Blaszkowsky LS, Enzinger PC, Ryan DP, Abrams TA, Zhu AX, et al. A multicenter phase II trial of single-agent cetuximab in advanced esophageal and gastric adenocarcinoma. Ann Oncol. 2011;22(6):1367-73. doi:10.1093/annonc/mdq604.

15. Kim C, Lee JL, Ryu MH, Chang HM, Kim TW, Lim HY, et al. A prospective phase II study of cetuximab in combination with XELOX (capecitabine and oxaliplatin) in patients with metastatic and/or recurrent advanced gastric cancer. Invest New Drugs. 2011;29(2):366-73. doi:10.1007/s10637-009-9363-0.

16. Lordick F, Luber B, Lorenzen S, Hegewisch-Becker S, Folprecht G, Woll E, et al. Cetuximab plus oxaliplatin/leucovorin/5-fluorouracil in first-line metastatic gastric cancer: a phase II study of the Arbeitsgemeinschaft Internistische Onkologie (AIO). Br J Cancer. 2010;102(3):500-5. doi:10.1038/sj.bjc.6605521.

17. Moehler M, Mueller A, Trarbach T, Lordick F, Seufferlein T, Kubicka $\mathrm{S}$, et al. Cetuximab with irinotecan, folinic acid and 5-fluorouracil as first-line treatment in advanced gastroesophageal cancer: a prospective multi-center biomarker-oriented phase II study. Ann Oncol. 2011;22(6):1358-66. doi:10.1093/ annonc/mdq591.

18. Rao S, Starling N, Cunningham D, Sumpter K, Gilligan D, Ruhstaller T, et al. Matuzumab plus epirubicin, cisplatin and capecitabine (ECX) compared with epirubicin, cisplatin and capecitabine alone as first-line treatment in patients with advanced oesophago-gastric cancer: a randomised, multicentre open-label phase II study. Ann Oncol. 2010;21(11):2213-9. doi:10.1093/annonc/mdq247.

19. Trarbach T, Przyborek M, Schleucher N, Heeger S, Lüpfert C, Vanhoefer U. Phase I study of matuzumab in combination with 5-fluorouracil, leucovorin and cisplatin (PLF) in patients with advanced gastric and esophagogastric adenocarcinomas. Invest New Drugs. 2013;31(3):642-52. doi:10.1007/s10637-012-98480 .

20. Schoennemann KR, Bjerregaard JK, Hansen TP, De Stricker K, Gjerstorff MF, Jensen HA, et al. Biweekly cetuximab and irinotecan as second-line therapy in patients with gastroesophageal cancer previously treated with platinum. Gastric Cancer. 2011;14(3):219-25. doi:10.1007/s10120-011-0031-7.

21. Tebbutt NC, Price TJ, Sjoquist KM, Veillard AS, Hall M, Ferraro DA, et al. Australasian GI trials group. Final results of AGITG ATTAX3 study: randomized phase II study of weekly docetaxel (T), cisplatin, and fluoropyrimidine $(\mathrm{F})$ with or without panitumumab $(\mathrm{P})$ in advanced esophagogastric (OG) cancer. J Clin Oncol. 2013;31 (suppl; abstr 4081).

22. Satoh T, Lee KH, Rha SY, Sasaki Y, Park SH, Komatsu Y, et al. Randomized phase II trial of nimotuzumab plus irinotecan versus irinotecan alone as second-line therapy for patients with advanced gastric cancer. Gastric Cancer. 2015;18:824-32.

23. Waddell T, Chau I, Cunningham D, Gonzalez D, Okines AF, Okines C, et al. Epirubicin, oxaliplatin, and capecitabine with or without panitumumab for patients with previously untreated advanced oesophagogastric cancer (REAL3): a randomised, open-label phase 3 trial. Lancet Oncol. 2013;14(6):481-9. doi:10. 1016/S1470-2045(13)70096-2.

24. Lordick F, Kang YK, Chung HC, Salman P, Oh SC, Bodoky G, et al. Capecitabine and cisplatin with or without cetuximab for 
patients with previously untreated advanced gastric cancer (EXPAND): a randomised, open-label phase 3 trial. Lancet Oncol. 2013;14(6):490-9. doi:10.1016/S14702045(13)70102-5.

25. Lordick F, Kang YK, Salman P, Oh SC, Bodoky G, Kurteva GP, et al. Clinical outcome according to tumor HER2 status and EGFR expression in advanced gastric cancer patients from the EXPAND study. J Clin Oncol. 2013;31 (suppl; abstr 4021).

26. Bang YJ, Van Cutsem E, Feyereislova A, Chung HC, Shen L, Sawaki A, et al. Trastuzumab in combination with chemotherapy versus chemotherapy alone for treatment of HER2-positive advanced gastric or gastro-oesophageal junction cancer (ToGA): a phase 3, open-label, randomized controlled trial. Lancet. 2010;376(9742):687-97. doi:10.1016/S0140-6736(10)61121-X.

27. Hecht JR, Bang YJ, Qin S, Chung HC, Xu JM, Park JO, et al. Lapatinib in combination with capecitabine plus oxaliplatin (CapeOx) in HER2-positive advanced or metastatic gastric, esophageal, or gastroesophageal adenocarcinoma (AC): The TRIO013/LOGiCTrial. J Clin Oncol. 2013;31 (suppl; abstr LBA4001).

28. Satoh T, Xu RH, Chung HC, Sun GP, Doi T, Xu JM, et al. Lapatinib plus paclitaxel versus paclitaxel alone in the secondline treatment of HER2-amplified advanced gastric cancer in Asian populations: TyTAN-a randomized, phase III study. J Clin Oncol. 2014;32(19):2039-49. doi:10.1200/JCO.2013.53.6136.

29. Kang YK, Shah MA, Ohtsu A, Van Cutsem E, Ajani JA, van der Horst AT, et al. A randomized, open-label, multicenter, adaptive phase $2 / 3$ study of trastuzumab emtansine (T-DM1) versus a taxane (TAX) in patients (pts) with previously treated HER2positive locally advanced or metastatic gastric/gastroesophageal junction adenocarcinoma (LA/MGC/GEJC). J Clin Oncol. 2016;34 (suppl 4S; abstr 5).

30. Tabernero J, Hoff PM, Shen L, Ohtsu A, Yu R, Eng-Wong J, et al. Pertuzumab $(\mathrm{P})$ with trastuzumab $(\mathrm{T})$ and chemotherapy (CTX) in patients (pts) with HER2 positive metastatic gastric or gastroesophageal junction (GEJ) cancer: An international phase III study (JACOB). J Clin Oncol 2013;31 (suppl; abstr TPS4150).

31. Wainberg Z, Lin L, DiCarlo B, Dao K, Patel R, Park D, et al. Phase II trial of modified FOLFOX6 and erlotinib in patients with metastatic or advanced adenocarcinoma of the oesophagus and gastro-oesophageal junction. $\mathrm{Br} \mathrm{J}$ Cancer. 2011;105:760-5. doi:10.1038/bjc.2011.280.

32. Dragovich T, McCoy S, Fenoglio-Preiser CM, Wang J, Benedetti $\mathrm{JK}$, Baker $\mathrm{AB}$, et al. Phase II Trial of Erlotinib in Gastroesophageal Junction and Gastric Adenocarcinomas: SWOG 0127. J Clin Oncol. 2006;24:4922-7.

33. Ilson DH, Kelsen D, Shah M, Schwartz G, Levine DA, Jeff Boyd J, et al. A phase 2 trial of erlotinib in patients with previously treated squamous cell and adenocarcinoma of the esophagus. Cancer. 2011;117:1409-14. doi:10.1002/cncr.25602.

34. Adelstein DJ, Rodriguez CP, Rybicki LA, Ives DI, Rice TW. A phase II trial of gefitinib for recurrent or metastatic cancer of the esophagus or gastroesophageal junction. Invest New Drugs. 2012;30(4):1684-9. doi:10.1007/s10637-011-9736-z.

35. Ferry DR, Anderson M, Beddard K, Tomlinson S, Atherfold P, Obszynska $\mathbf{J}$, et al. A phase II study of gefitinib monotherapy in advanced esophageal adenocarcinoma: evidence of gene expression, cellular, and clinical response. Clin Cancer Res. 2007;13(19):5869-75.

36. Lurje G, Leers JM, Pohl A, Oezcelik A, Zhang W, Ayazi S, et al. Genetic variations in angiogenesis pathway genes predict tumor recurrence in localized adenocarcinoma of the esophagus. Ann Surg. 2010;251(5):857-64. doi:10.1097/SLA.0b013e3181c97fcf.

37. Ohtsu A, Shah MA, Van Cutsem E, Rha SY, Sawaki A, Park SR, et al. Bevacizumab in combination with chemotherapy as firstline therapy in advanced gastric cancer: a randomized, double- blind, placebo-controlled phase III study. J Clin Oncol. 2011;29(30):3968-76. doi:10.1200/JCO.2011.36.2236.

38. Van Cutsem E, de Haas S, Kang YK, Ohtsu A, Tebbutt NC, Xu JM, et al. Bevacizumab in Combination With Chemotherapy As First-Line Therapy in Advanced Gastric Cancer: a Biomarker Evaluation From the AVAGAST Randomized Phase III Trial. J Clin Oncol. 2012;30:2119-27.

39. Li J, Kortmansky JS, Fischbach NA, Stein S, Yao X, Hochster HS, et al. Phase II study of mFOLFOX with bevacizumab (Bev) in metastatic gastroesophageal and gastric (GE) adenocarcinoma (AC). J Clin Oncol. 2013;31 (suppl; abstr 4084).

40. Purim O, Kundel Y, Gonik US, Idelevich E, Medalia G, Gordon $\mathrm{N}$, et al. Weekly docetaxel and cisplatin with capecitabine and bevacizumab (AVDCX) in patients with advanced esophagogastric cancer: Results of a phase Ib/II study. J Clin Oncol. 2013;31 (suppl; abstr e15078).

41. Fuchs CS, Tomasek J, Yong CJ, Dumitru F, Passalacqua R, Goswami $\mathrm{C}$, et al. REGARD Trial Investigators. Ramucirumab monotherapy for previously treated advanced gastric or gastro-oesophageal junction adenocarcinoma (REGARD): an international, randomised, multicentre, placebo-controlled, phase 3 trial. Lancet. 2014;383(9911):31-9 doi:10.1016/S0140-6736(13)61719-5].

42. Wilke H, Van Cutsem E, Oh SC, Bodoky G, Shimada Y, Hironaka S, et al. RAINBOW: A global, phase III, randomized, double-blind study of ramucirumab plus paclitaxel versus placebo plus paclitaxel in the treatment of metastatic gastroesophageal junction (GEJ) and gastric adenocarcinoma following disease progression on first-line platinum and fluoropyrimidine containing combination therapy RAINBOW IMCL CP120922 (I4TIEJVBE). J Clin Oncol. 2014;32 (Suppl 3; abstr LBA7).

43. Fuchs CS, Tomasek J, Cho JY, Tomasello G, Goswami C, Dos Santos LV, et al. REGARD: A phase 3, randomized, double-blind trial of ramucirumab (RAM) and best supportive care (BSC) versus placebo (PL) and BSC in the treatment of metastatic gastric or gastroesophageal junction (GEJ) adenocarcinoma following disease progression (PD) on first-line platinum-and/or fluoropyrimidine containing combination therapy: Age subgroup analysis. J Clin Oncol. 2014;32 (suppl 5s; abstr 4057).

44. Wilke H, Van Cutsem E, Oh SC, Bodoky G, Shimada Y, Hironaka S, et al. RAINBOW: A global, phase 3, randomized, double-blind study of ramucirumab plus paclitaxel versus placebo plus paclitaxel in the treatment of metastatic gastric adenocarcinoma following disease progression on first-line platinum-and fluoropyrimidine-containing combination therapy: Results of a multiple Cox regression analysis adjusting for prognostic factors. J Clin Oncol. 2014;32 (suppl 5s; abstr 4076).

45. Al-Batran SE, Van Cutsem E, Oh SC, Bodoky G, Shimada Y, Hironaka S, et al. RAINBOW: A global, phase III, randomized, double-blind study of ramucirumab plus paclitaxel versus placebo plus paclitaxel patients with previously treated gastric or gastroesophageal junction (GEJ) adenocarcinoma: Quality-of-life (QoL) results. J Clin Oncol. 2014;32 (suppl 5s; abstr 4058).

46. Hironaka S, Shimada Y, Sugimoto N, Komatsu Y, Nishina T, Yamaguchi K, et al. RAINBOW: A global, phase III, randomized, double-blind study of ramucirumab (RAM) plus paclitaxel (PTX) versus placebo (PL) plus PTX in the treatment of metastatic gastroesophageal junction and gastric adenocarcinoma (mGC) following disease progression on first-line platinum-and fluoropyrimidine-containing combination therapy-efficacy analysis in Japanese and Western patients. J Clin Oncol. 2014;32 (suppl 5s; abstr 4005).

47. Tabernero J, Ohtsu A, Muro K, Van Cutsem E, Oh SC, Bodoky $\mathrm{G}$, et al. Exposure-response relationship of ramucirumab from two global, randomized, double blind, phase 3 studies of patients with advanced second-line gastric cancer. J Clin Oncol. 2015;33 (suppl 3; abstr 121). 
48. Yoon HH, Bendell JC, Braiteh FS, Firdaus I, Philip PA, Cohn AL, et al. Ramucirumab (RAM) plus FOLFOX as front-line therapy (Rx) for advanced gastric or esophageal adenocarcinoma (GEAC): Randomized, double-blind, multicenter phase 2 trial. J Clin Oncol. 2014;32 (suppl 5s; abstr 4004).

49. Moehler MH, Thuss-Patience PC, Schmoll HJ, HegewischBecker S, Wilke H, Al-Batran SE, et al. FOLFIRI plus sunitinib versus FOLFIRI alone in advanced chemorefractory esophagogastric cancer patients: a randomized placebo-controlled multicentric AIO phase II trial. J Clin Oncol. 2013;31 (suppl; abstr 4086).

50. Bang YJ, Kang YK, Kang WK, Boku N, Chung HC, Chen JS, et al. Phase II study of sunitinib as second-line treatment for advanced gastric cancer. Invest New Drugs. 2011;29(6):1449-58. doi:10.1007/s10637-010-9438-y.

51. Moehler M, Mueller A, Hartmann JT, Ebert MP, Al-Batran SE, Reimer P, et al. Arbeitsgemeinschaft Internistische Onkologie (AIO). An open-label, multicentre biomarker-oriented AIO phase II trial of sunitinib for patients with chemo-refractory advanced gastric cancer. Eur J Cancer. 2011;47(10):1511-20. doi:10.1016/ j.ejca.2011.04.006.

52. Martin-Richard M, Gallego R, Pericay C, Garcia Foncillas J, Queralt B, Casado E, et al. Multicenter phase II study of oxaliplatin and sorafenib in advanced gastric adenocarcinoma after failure of cisplatin and fluoropyrimidine treatment. A GEMCAD study. Invest New Drugs. 2013;31(6):1573-9.

53. Sun W, Powell M, O’Dwyer PJ, Catalano P, Ansari RH, Benson AB 3rd. Phase II study of. sorafenib in combination with docetaxel and cisplatin in the treatment of metastatic or advanced gastric and gastroesophageal junction adenocarcinoma: ECOG 5203. J Clin Oncol. 2010;28(18):2947-51. doi:10.1200/JCO. 2009.27.7988.

54. Pavlakis N, Sjoquist KM, Tsobanis E, Martin AJ, Kang YK, Bang YJ, et al. INTEGRATE: A randomized, phase II, double-blind, placebo-controlled study of regorafenib in refractory advanced oesophagogastric cancer (AOGC): A study by the Australasian Gastrointestinal Trials Group (AGITG)—final overall and subgroup results. J Clin Oncol. 2015;33 (suppl; abstr 4003).

55. Yip S, Harvie R, Martin AJ, Sjoquist KM, Tsobanis E, Kang YK, et al. Evaluation of circulating VEGF based biomarkers in INTEGRATE: A randomized phase II double-blind placebocontrolled study of regorafenib in refractory advanced oesophagogastric cancer (AOGC) - A study by the Australasian Gastrointestinal Trials Group (AGITG). J Clin Oncol. 2016;34 (Suppl 4s; abstr 64).

56. Li J, Qin S, Xu J, Xiong J, Wu C, Bai Y, et al. Randomized, double-blind, placebo-controlled phase III trial of Apatinib in patients with chemotherapy-refractory advanced or metastatic adenocarcinoma of the stomach or gastroesophageal junction. J Clin Oncol. 2016;34(13):1448-54. doi:10.1200/JCO.2015.63. 5995.

57. Hack SP, Bruey JM, Koeppen H. HGF/MET-directed therapeutics in gastroesophageal cancer: a review of clinical and biomarker development. Oncotarget. 2014;5(10):2866-80.

58. Li Y, An X, Wang F, Shao Q, Wang FH, Wang Z, et al. MET amplification occurrence and prediction of unfavorable clinical outcomes in patients with recurrent/metastatic gastric cancer after chemotherapy. J Clin Oncol. 2013;31 (suppl; abstr e15047).

59. Smith EC, Sclafani F, Cunningham D. Emerging molecular targets in oncology: clinical potential of MET/hepatocyte growthfactor inhibitors. Onco Targets Ther. 2014;7:1001-14. doi:10. 2147/OTT.S44941.
60. Oliner KS, Tang R, Anderson A, Lan Y, Iveson T, Donehower $\mathrm{RC}$, et al. Evaluation of MET pathway biomarkers in a phase II study of rilotumumab (R, AMG 102) or placebo (P) in combination with epirubicin, cisplatin, and capecitabine (ECX) in patients (pts) with locally advanced or metastatic gastric $(\mathrm{G})$ or esophagogastric junction (EGJ) cancer. J Clin Oncol. 2012;30 (suppl; abstr 4005).

61. Cunningham D, Tebbutt NC, Davidenko I, Murad AM, Al-Batran SE, Ilson DH, et al. Phase III, randomized, double-blind, multicenter, placebo $(\mathrm{P})$-controlled trial of rilotumumab $(\mathrm{R})$ plus epirubicin, cisplatin and capecitabine (ECX) as first-line therapy in patients (pts) with advanced MET-positive (pos) gastric or gastroesophageal junction (G/GEJ) cancer: RILOMET-1 study. Clin Oncol. 2015;33 (suppl; abstr 4000).

62. Doi T, Yamaguchi K, Komatsu Y, Muro K, Nishina T, Nakajima TE, et al. Safety, tolerability, and pharmacokinetics (PK) of rilotumumab (R) combined with cisplatin (C) and capecitabine (X) in Japanese patients (pts) with MET-positive metastatic gastric or gastroesophageal junction (G/GEJ) adenocarcinoma. J Clin Oncol. 2014;32 (suppl 5s; abstr 4051).

63. Shah MA, Cho JY, Huat ITB, Tebbutt NC, Yen CJ, Kang A, et al. Randomized phase II study of FOLFOX +/- MET inhibitor, onartuzumab $(\mathrm{O})$, in advanced gastroesophageal adenocarcinoma (GEC). J Clin Oncol. 2015;33 (suppl 3; abstr 2).

64. Shah MA, Bang YJ, Lordick F, Tabernero J, Chen M, Hack SP, et al. METGastric: A phase III study of onartuzumab plus mFOLFOX6 in patients with metastatic HER2-negative (HER2-) and MET-positive (MET +) adenocarcinoma of the stomach or gastroesophageal junction (GEC). J Clin Oncol. 2015;33 (suppl; abstr 4012).

65. Kwak EL, LoRusso P, Hamid O, Janku F, Kittaneh M, Catenacci DVT, et al. Clinical activity of AMG 337, an oral MET kinase inhibitor, in adult patients (pts) with MET-amplified gastroesophageal junction (GEJ), gastric (G), or esophageal (E) cancer. J Clin Oncol. 2015;33 (suppl 3; abstr 1).

66. Doi T, Muro K, Boku N, Yamada Y, Nishina T, Takiuchi H, et al. Multicenter phase II study of everolimus in patients with previously treated metastatic gastric cancer. J Clin Oncol. 2010;28(11):1904-10. doi:10.1200/JCO.2009.26.2923.

67. Ohtsu A, Ajani JA, Bai YX, Bang YJ, Chung HC, Pan HM, et al. Everolimus for previously treated advanced gastric cancer: results of the randomized, double-blind, phase III GRANITE-1 study. J Clin Oncol. 2013;31(31):3935-43. doi:10.1200/JCO.2012.48. 3552.

68. Muro K, Bang YJ, Shankaran V, Geva R, Catenacci DVT, Gupta $\mathrm{S}$, et al. A phase 1B study of Pembrolizumab (PEMBRO; MK3475) in patients (PTS) with advanced gastric cancer. Ann Oncol. 2014;25 (suppl 5):v1v41.

69. Muro K, Bang YJ, Shankaran V, Geva R, Catenacci DVT, Gupta $\mathrm{S}$, et al. Relationship between PDL-1 expression and clinical outcomes in patients (Pts) with advanced gastric cancer treated with the anti-PD-1 monoclonal antibody pembrolizumab (Pembro; MK-3475) in KEYNOTE-012. J Clin Oncol. 2015;33 (suppl 3; abstr 3).

70. Haj Mohammad N, Ter Veer E, Ngai L, Mali R, van Oijen MG, et al. Optimal first-line chemotherapeutic treatment in patients with locally advanced or metastatic esophagogastric carcinoma: triplet versus doublet chemotherapy: a systematic literature review and meta-analysis. Cancer Metastasis Rev. 2015;34(3):429-41. doi:10.1007/s10555-015-9576-y. 